\title{
The Contradictory Leadership in Orwell's Animal Farm as Perspective of Buginese
}

\author{
A. Ilah Nurul Falah ${ }^{1}$, Herawaty Abbas $^{2}$, Burhanuddin Arafah ${ }^{3}$, Irmawati $^{4}$ \\ \{falahain17f@student.unhas.ac.id ${ }^{1}$, herawaty@unhas.ac.id², burhan-arafah@unhas.ac.id ${ }^{3}$, \\ irmawati17f@student.unhas.ac.id $\left.{ }^{4}\right\}$ \\ Universitas Hasanuddin, Indonesia ${ }^{1,2,3,4}$
}

\begin{abstract}
The research aims to elaborate the leadership model's contradictory of Buginesse perspective based on the characters in Animal Farm by Orwell. This research is associated the external theory to know the concept of leadership values contradictory between leadership values in Buginesse perspective and leadership values in Orwell's Animal Farm. Then, the researchers analyzed the leadership values that reflected in the novel using Abram's sociology literature approach and mimetic perspective that focuses on the relationship between literary works and the universe that inspires the creation of literary works, if one applies the mimetic approach. The researchers use qualitative method both for collecting and analyzing data. The results of this study indicate that there are five leadership values of Buginesse perspective. Four of them are contradictive with leadership in Orwell's Animal Farm such as Lempu means honest and truthful, Getteng means firm, brave, and strong on the establishment, Ada Tongeng means hold fast to the truth, Sugik means rich in thought word, work, and spending. There is one Buginese leadership value that is has similarity with leadership value in Orwell's Animal Farm.
\end{abstract}

Keywords: Animal Farm, Buginese, Leadership, Mimetic, Sociology Literature Approach

\section{Introduction}

Literature work is the reflection of human life. It included the theme, characterization of the character, setting and place. Through the literary work, the writer expressed his or her idea such as through works like short story, novel, poetry, drama, etc.

Animal Farm is an allegorical novella by George Orwell, it first published in England on 17 August 1945. The poorly-run Manor Farm near Willingdon, England is ripened for rebellion from its animal populace by neglect at the hands of the irresponsible and alcoholic farmer, Mr. Jones. One night, the exalted boar Old Major organizes a meeting, at which he calls for the overthrow of humans and taught the animals a revolutionary song called "Beasts of England". When Old Major dies, two young pigs, Snowball and Napoleon, assume command and stage a revolt, driving Mr. Jones off the farm and renaming the property "Animal Farm". They adopted the Seven Commandments of Animalism, the most important of which was, "All animals are equal".

The decree is painted in large letters on one side of the barn. Snowball taught the animals to read and write, while Napoleon educated young puppies on the principles of Animalism. Food is plentiful, and the farm ran smoothly. The pigs elevate themselves to positions of leadership and set aside special food items, ostensibly for their personal health. Following an unsuccessful attempt by Mr. Jones and his associates to retake the farm (later dubbed the "Battle of the 
Cowshed"), Snowball announces his plans to modernize the farm by building a windmill. Napoleon has his dogs chased Snowball away and he declared himself leader.

Buginese tribe was one of the biggest societies in South Sulawesi. Like other tribe, the Buginese people had their own methodologies relating to their life, which included the right to leader in their society.

There were some people who think that literature was only for entertainment or enjoyment. This was not more complete view because literature was not only about entertainment and enjoyment but it also contained ideas on the reflection of real life that could be a portrait of human life. As Wellek and Warren [1] stated literature is a social institution that using as its medium language, a social creation. Such traditional literary devices as symbolism ammeter are social in their very nature. They are conventions and norm which could have arisen only in society. But, furthermore, literature represents "life" and "life" is in large measure, a social reality, even though the natural world and the inner or subjective world of the individual has also been objects of literary "imitation". The poet himself is a member of society, possessed of a specific social status: he receives some degree of social recognition and reward; he addressed an audience, however hypothetical.

It showed that literature as a work from the author that showed a complete portrait of human life. Through expression and language, literature has a direct correlation with social life. In other words, it could be said if there was close relationship between literature and human life. Through literature, we could enrich our knowledge and experiences, since literature was a reflection of human life. Furthermore, reading literature did not simply for enjoyment, pleasure and excitement, but we could dig out the meaning inside because literature was the medium for learning about life. The word desire simply means that someone in the relationship, perhaps just the person in a leadership role, wants a particular outcome.

A leader is one or more people who selects, equips, trains, and influences one or more follower(s) who have diverse gifts, abilities, and skills and focuses the follower(s) to the organization's mission and objectives causing the follower(s) to willingly and enthusiastically expend spiritual, emotional, and physical energy in a concerted coordinated effort to achieve the organizational mission and objectives. The leader achieves this influence by humbly conveying a prophetic vision of the future in clear terms that resonates with the follower(s) beliefs and values in such a way that the follower(s) can understand and interpret the future into present-time action steps. In this process, the leader presents the prophetic vision in contrast to the present status of the organization and through the use of critical thinking skills, insight, intuition, and the use of both persuasive rhetoric and interpersonal communication including both active listening and positive discourse, facilitates and draws forth the opinions and beliefs of the followers such that the followers move through ambiguity toward clarity of understanding and shared insight that results in influencing the follower(s) to see and accept the future state of the organization as a desirable condition worth committing personal and corporate resources toward its achievement [2].

In Etymological, sociology comes from the word 'socio' or 'society' that means 'society' of 'logos' means science. Thus, in a simple sense, sociology is the science of society or the science of the life of society. In a broader sense, sociology is an objective and scientific study of people in society, the study of the institution and social processes. Therefore, the sociology approach is usually applied to analyze human in society with the process of understanding from the community to the human as an individual.

In his book entitled The Mirror and the Lamp (1976), Abrams introduces the concept of the universe. Through this concept, Abrams conveys four interconnected elements that build the literary works. (1) literary work itself as a work of art. (2) The creator/author of literary works 
(3) the universe that inspires the creation of literary works, and (4) the reader of literary works

[3]. Furthermore, Abrams stated:

Four elements in the total situation of a work of art are discriminated and made salient, by one or another synonym in almost all theories which aim to be comprehensive. First, there is the work, the artist product itself. And since this is a human product, an artifact the second common element is the artificer, the artist. Third, the work is taken to have a subject which directly or deviously, is derived from existing things-to be about, or signify, or reflect something which either is, or bears some relation to, an objective state of affairs. This third element, whether held to consist of people and actions, ideas and feelings, material things and events, or super-sensible essences, has frequently been denoted by that word-all-work 'nature but let us use the more neutral and comprehensive term universe, instead For the final element we have the audience the listeners, spectators or readers to whom the work of art is addressed [3].

Based on the theory, literary works can be observed through four perspectives; (a) expressive, (b) mimetic, (c) pragmatic, and (d) objective. Such perspectives towards literary works are further elaborated by Lewis [4] which states that in analyzing literary works, the work itself can be focused on (a) the author, if one applies the expressive approach, (b) the relationship between literary works and the universe that inspires the creation of literary works, if one applies the mimetic approach, (c) the effect of literary works towards readers, if one applies pragmatic approach and (d) the literary works as an autonomous entity, an artifact which structural characteristics can be identified, if one applies the objective approach.

Literature as a reflection of society and not born of cultural emptiness can be studied interdisciplinary. Interdisciplinary literary studies are theories that use other assistive disciplines in studying literature, and look at their relationship with other broader disciplines.

This shows that literary works are essentially a reflection of the state value and life of the community in accordance with their views and ideology. Therefore, public relations with literature are mediated by the authors. By looking at this fact, the sociology of literature makes the writer as an individual who needs to be the focus of her study. Literary is often authenticated to examine the author's ideology of world view of existing conditions of society.

The relationship between sociology and literature is mediated by literary facts. Literary facts in a literary work are the form of events whose aspects are character place and time. The relationship between sociology and literature is mediated by the reader. Literary work is essentially a cultural product that will be meaningful if there is communication with the reader through the reader's interpretation. Literary work remains meaningless. This is what makes the study focus on the reader. The reader is the giver of meaning to the existence of literary works. Therefore, an analysis of the meaning of the reader towards literary works becomes an important part.

There are some Buginese scholars who think about the characteristics of leaders who are considered ideal. Including Kajaolalido and MaccaE ri Luwu. The following is an explanation of the requirements for a leader to be considered an ideal leader.

[...] Kajaolalido put the lempuk (honest), ada-tongeng (correct words), getteng (firm and resolute) and sipkatau (mutual respect as fellow human beings) as the primary base value which is supplemented by the subsider basic value of the amaccang (intelligence). [...] [5]. 
La Mellong that known as To Suwalle Kajaolalido has some characteristics that can become a measurement for a good leader. Those are lempu means honest, ada tongeng means correct word, getteng means firm and sipakatau means mutual respect as fellow human beings. From those characteristics if added by macca, clever, it will be a perfect ideal leader.

Ibrahim in Sulesana said La Waniaga Arung Bila is expressing a number of values underlie and animate his thoughts. Those values are there are four kinds of glowing gems, namely the first is honesty; secondly is correct words and resolve (consistency of right speech); the third is sirik with accompanied determination; the fourth is thought and kindness. Lempu values means honest, ada tongeng means correct word; getteng means determination on the establishment, sirik means dignity and self-worth. Those are mentioned as value symbolized by the word paramata-mattappa. Paramata-mattappa means the glowing gem. These values are often covered by variety human nature. Honesty is covered by tendencies doing arbitrary deeds, true words covered by lying; sirik covered by greed; and the mind is covered by anger [5].

[...] MaccaE ri Luwu put forward the criteria to become an official or state apparatus namely malempukpi (who has honesty), kenawa - nawapi (long-thinking), sugikpi (who has wealth) and warrani (who have courage) [...] [5].

Ibrahim stated in Sulesana that according to MaccaE ri Luwu, the sign of an honest person (malempuk) is a person who is guilty of being forgiven he is trusted and does not betray that trust, is not greedy or does not want that is not his right and does not demand a kindness, if only he is enjoying it or only for his own interests. The sign of a long-thinking person is that he likes the right behavior, he likes the right words, when faced with thickets (things that are misleading), he retreats to avoid it, and if he goes through the road, he is careful. As for the sign of the rich (sugik) is rich in words, rich in thought, rich in work, and rich in shopping. The sign of a brave person is not to be afraid of facing bad words or good words, and not afraid to be placed in front or behind [5].

From those three though, there are 13 requirements that become measurement of a good leader. 9 of them has similarity, there are lempu, ada tongeng and getteng. Then there are 4 values that have differences of each other. Those are sipakatau value from Kajaolalido, sirik value from Arung Bila then kenawa - nawa, sugik and warani from MaccaE ri Luwu.

Sipakatau considers a bunch of sugik. Someone who sugik, means rich in word and rich in work and has amaccang must be has sipakau value. Sirik value considers a bunch of getting. In the other hand, sirik also can be a part of lempu and ada tongeng. Buginese people are very caring about lempu, getting and tonging, if one of the is missing it can be related to sirik. Kenawa - nawa considers a bunch of macca. A clever one must be having a long thinking before decides something. The position of that person is an important position in a community or organization can be a consideration because the long thinking is needed. Warani means brave. To becomes a firm one, the person must be a brave person. So, the researcher considers warani is a part of getting. There are 5 values that still exist in Buginese people environment and they still consider these five requirements before choose a good leader in their community. Begin with Head of a village until a president of a country. There are, lempu' ((honest), getteng (firm and resolute), ada tongeng (correct words), sugik (rich) and macca (clever).

According to Dictionsr.com contradictory is asserting the contrary or opposite, contradicting, inconsistent, logically opposite. To explain about differences, opposite or inconsistent of some things is called contradictory from that we can conclude the differences of two or more things. 
Two main ideas contained in literature were value and beauty. Perhaps an aspect of value was meaning because literature always conveys value or meaning to the reader. The concept of beauty refers to the beauty of people lived depicted in literary works and the beauty of the language used for conveying life.

On the other hand, literature in terms of its culture was as a result of creativity in the form of thought and feeling that was poured through media of language. Therefore, collective literature was the result of human culture which was generally manifested through a language system, and language itself was an element of culture which was largely represented by human thoughts and feelings as social beings. Because literature was a product of culture, literature besides describing the ideas and thoughts of its authors, literature also described social and cultural systems as the place where the writer lived. Thus, literature was a cultural product that described the social activities of the people represented by their characters in a particular setting and time.

\section{Methodology}

In carrying out this study, the researcher used a descriptive qualitative method. In collecting the data, the researcher wrote the data that relates with society in era of revolution based on the source of data. Then, the researcher used a library research method to collect supporting data from some books, journals, articles and information from the internet that relate to this research.

The researcher used library research to obtain via books that were relevant with the object of research. Primary data were data that derived from the novel "Animal Farm" written by George Orwell. The novel was published in England on August 17, 1945. The step used to understand the primary data are as follows: 1 . Reading the novel with accuracy; 2 . Analyzing conjunctures of the novel; 3 . Analyzing and describing the social life and role of society based on social class in the novel "Animal Farm". Supporting data were data obtained outside of the novel Animal Farm that helped in the research of this thesis. There are some books about Buginese leadership's perspective such as Latoa, The Buginese, Sulesana, and Silasa. These other supporting data were obtained via books, theses, and articles relevant to this study.

There were four instruments which were necessarily required in conducting this research. These instruments were: 1 . Stabilo is using to highlight the important data that had found either in the novel or the other printed sources; 2 . Small notebook is using to save all the brainstormed ideas which put the researcher in easy during the process of the data analysis; 3 . Pen and pencil are using to write some important notes that is related to the research; 4. Sticky notes are using to mark every important page in the novel or the other printed sources; 5 . Laptop is used to type and save the data, including the thesis data, some articles and books.

In this research, the researcher conducted library research. The method of collecting data includes: 1 . Reading the novel carefully; 2. Taking notes on the data that relates to society in the era of revolution; 3. Providing particular fragments of data that support the research questions. Descriptive analysis was used in this study to analyze the novel. Analysis was carried out after following the steps to describe things that occur in the novel, such as conflicts between characters, plot, and so on. To analyze the data, the researcher used the sociology literature approach. The steps to analyze data were: Analyzing the intrinsic elements of the novel to find out the characters and characterization of the novel, and analyzing the extrinsic elements of the novel finding the leadership in the "Animal Farm" novel. 
In this research, the researcher used several steps to take information from primary and supporting data, they were: 1 . Reading the novel carefully as the main source; 2 . Reading the books, theses and articles that support the research; 3. Identifying the scope of problems to be analyzed; 4. Classifying and limit the problems of the research; 5. Obtaining all data and information which have relevance to the subject from the other references; 6 . Analyzing the data; 7. Making a conclusion and suggestions that supports the research.

\section{Findings and Discussion}

\subsection{Findings}

This research in this part, the researcher begins to present the data that had been found in the novel Animal Farm by Orwell. The researcher focused on the contradictory of leadership in Animal Farm and showed to what extend the roles of society played in their social class throughout the story. Then, the researcher explained the data that had been found.

\subsubsection{Ambitious}

Ambitious is someone who has strong desire to be successful or to do something. Some people who have any desire to be leader of a community or organization are have ambitious. In this novel there are Mr. Jones and Napoleon who are ambitious.

Data 1: Early in October, when the corn was cut and stacked and some of it was already threshed, a flight of pigeons came whirling through the air and alighted in the yard of Animal Farm in the wildest excitement. Jones and all his men, with half a dozen others from Foxwood and Pinch field, had entered the five-barred gate and were coming up the cart-track that led to the farm. They were all carrying sticks, except Jones, who was marching ahead with a gun in his hands. Obviously, they were going to attempt the recapture of the farm [6].

Mr. Jones did not give up and let the farm owned by the animals. He tried to come back to attack the animal which are already drove him out and take his farm back. He comes with some friends and their sticks.

Data 2: Silent and terrified, the animals crept back into the barn. In a moment the dogs came bounding back. At first no one had been able to imagine where these creatures came from, but the problem was soon solved: they were the puppies whom Napoleon had taken away from their mothers and reared privately. Though not yet full-grown, they were huge dogs, and as fierce looking as wolves. They kept close to Napoleon. It was noticed that they wagged their tails to him in the same way as the other dogs had been used to do to Mr. Jones [6].

Napoleon is a cutthroat one. He takes the puppies and raises silently them to protect him one day. It is a cunning way to all animals in the farm. It shows that Napoleon is not a good one. He has bad characterization. Napoleon shows his ambition to take over the whole farm and purges Snowball so that he becomes the only leader. He prepares his plan completely. About 
the dogs that he raises, those dogs like weapon of him to against everyone who has different perspective with him.

In this part portrayed how Napoleon gained his position as the only leader since the expulsion of Snowball. One method he used was to separate the nine puppies from his mother and then quietly train them in the attic. From the data above, it can be seen that Napoleon's ambition to become the only leader was manifested in a dishonest way. This is certainly not in accordance with the leadership value in the perspective of the Buginese. There are five values of leadership held by the Buginese, namely lempu which means honest, getteng means firm, ada tongeng which means correct words, sugik means rich and macca means clever. The data above can be seen when Napoleon trained nine dogs in secret - then made the nine dogs as weapons to attack and finally drove Snowball from the farm. That is a not honest way to get the highest position.

\subsubsection{Manipulative}

Manipulative is tending to influence or control someone or something to your advantage, often without anyone knowing it. Most of the cases about manipulative are inclined negative things.

Data 3: "It was the most affecting sight I have ever seen!" said Squealer, lifting his trotter and wiping away a tear. "I was at his bedside at the very last. And at the end, almost too weak to speak, he whispered in my ear that his sole sorrow was to have passed on before the windmill was finished. 'Forward, comrades!' he whispered. 'Forward in the name of the Rebellion. Long live Animal Farm! Long live Comrade Napoleon! Napoleon is always right'. Those were his very last words, comrades". [6].

Data 4: That gave the animals pause, and there was a hush. Muriel began to spell out the words. But Benjamin pushed her aside and in the midst of a deadly silence he read: 'Alfred Simmonds, Horse Slaughterer and Glue Boiler, Willingdon. Dealer in Hides and Bone-Meal. Kennels Supplied'. Do you not understand what that means? They are taking Boxer to the knackers! [6].

The story of Boxer's death being manipulated by Squealer, he tells in detail how Boxer was dying in the hospital and at the end of his life Boxer praised Napoleon's leadership. Squealer reported as if Boxer died in the hospital but actually Boxer was sold to a slaughterhouse. The money from the sale of Boxer from the slaughterhouse was used to buy a box of whiskey. The death of Boxer in that way also is against the 7 commandments that no animal shall kill other animals.

Even other animal already realized about the pig's behavior, he does not have any power, the only thing that he can does is check the 7 commandments out and find a new additional word there.

Aline with that though, MaccaE ri Luwu in Ibrahim [5] said that adhere to the principle of truth (getteng) by not breaking promises, not betraying pledges, and not canceling fixed laws. so, it also does not go beyond the dividing or dividing line, it does not exaggerate its behavior or reduce its behavior, it does not exaggerate or reduce its words, or it exaggerates the experience of what it has seen. 
In Buginese perspective, to fight a leader to fight the leader even if it is permissible when the attitude of the leader has crossed the limits of the law that has been established together. In this part when viewed from the perspective of the Buginese, there are many things that are actually not in accordance with applicable law. The animals are not enough to fight. They just follow what their leader said.

\subsubsection{Dictatorship}

Dictatorship is a ruler with total power over a country, typically one who has obtained control by force. A dictator marked by a person who behaves in an autocratic way.

Data 5: By late summer a sufficient store of stone had accumulated, and then the building began, under the superintendence of the pigs [6].

Data 6: It was about this time that the pigs suddenly moved into the farmhouse and took up their residence there. Again, the animals seemed to remember that a resolution against this had been passed in the early days, and again Squealer was able to convince them that this was not the case. It was absolutely necessary, he said, that the pigs, who were the brains of the farm, should have a quiet place to work in. It was also more suited to the dignity of the Leader (for of late he had taken to speaking of Napoleon under the title of "Leader") to live in a house than in a mere stay. Nevertheless, some of the animals were disturbed when they heard that the pigs not only took their meals in the kitchen and used the drawing room as a recreation room, but also slept in the beds [6].

The seven commandments are arranged by the pigs as the leader of the all animal in the farm.

Finally, they tried to amend the commandments according to their desires. Such as live in the farm house, took the meal in the kitchen, and use the drawing room as a recreation room also sleep on the bed. Those things are human beings' usual things.

Finally, the pig's behavior as human being already, not only sleep in the bed and smoke, but also dressed, drink alcohol, eat in the farm house and sit in the chairs. All of the commandments already amended, the pig's behavior is totally changing.

The quotation above shows how the leader, Napoleon and other pigs lead the farm. How they violated almost all of the orders they had agreed to. They do things that are not in accordance with the initial conversation. This is not in accordance with one of the leadership values in Buginese perspective. True word means willing to say exactly what was going. In Ibrahim [5], Arung Bila said, as for what is called speech, pay close attention to both parties, witnesses of both parties, the establishment of both parties, deeds, 'barangkauk' of both parties.

\section{Pacippe' lilamu nabatela'mu}

Tunes your tongue and your tracks

*Notes from collection of Andi Macca Amirullah [7].

From these quotes, it shows that A person's value is determined by the way he harmonizes his words and actions. Increase in harmony with both, the higher the value of someone. It must be influence how people trust someone to do something or to keep something. 


\subsubsection{Careless}

According to Oxford Dictionary, careless means resulting from lack of attention and thought. Mr. Jones is a farmer and drunkard who owned the Manor Farm. He cares little for his farm, including the animals which live there.

Data 7: They were always cold, and usually hungry as well [6].

Napoleon and other pigs stay inside the farm house whether other animals are keep working the windmill outside. The weather is winter in that time and they are stay cold and hungry because Napoleon does not care about them anymore. These cases are contra with leadership values in Buginese perspective that a leader must be a sugik one. Sugik means rich, the leader in Orwell Animal Farm but they are not rich enough in Buginese view. Because they are not rich in word, rich in work, rich in thought and rich in shopping or spending.

\subsubsection{Clever}

Data 8: The work of teaching and organizing the others fell naturally upon the pigs, who were generally recognized as being the cleverest of the animals [6].

Data 28: They met with many difficulties - for instance, later in the year, when they harvested the corn, they had to tread it out in the ancient style and blow away the chaff with their breath, since the farm possessed no threshing machine - but the pigs with their cleverness and Boxer with his tremendous muscles always pulled them through [6].

Data 30: But Napoleon was too clever for him [6].

From those data above it show that Orwell wants to show that the pigs are clever and become the cleverest one among animals in the farm. In the beginning of the story, Orwell shows the old major with powerful character then Snowball and Napoleon. Those pigs become teacher and leader in that story. In Buginese perspective, one of leadership value is amaccang. It means cleverness, so in Kajaolalido's thinking, a leader must be clever. So that the leader can be a good leader

A clever one is a person who has superficially skillful. Beside that he or she has capacity for learning, reasoning, understanding, and similar forms of mental activity.

Table 1. The contradictory leadership of leadership values in Orwell's Animal Farm and Buginese Leadership values

\begin{tabular}{lcc}
\hline \multicolumn{1}{c}{$\begin{array}{c}\text { Leadership Values in Buginese } \\
\text { Perspective }\end{array}$} & $\begin{array}{c}\text { Orwell's Animal } \\
\text { Farm }\end{array}$ & $\begin{array}{c}\text { Buginese } \\
\text { Perspective }\end{array}$ \\
\hline Lempu' (Honest) & $\times$ & $\sqrt{ }$ \\
Getteng (Firm) & $\times$ & $\sqrt{ }$ \\
Ada Tongeng (Correct Word) & $\times$ & $\sqrt{ }$ \\
Sugik (Rich) & $\times$ & $\sqrt{ }$ \\
Macca (Clever) & $\sqrt{ }$ & $\sqrt{ }$ \\
\hline
\end{tabular}




\subsection{Discussion}

\subsubsection{Lempu (Honest)}

In the Buginese language means "straight". Lempu can also mean jackfruit. In this case, leтри means straight. Straight is the same as being honest. In the perspective of people, honesty is a very important thing to have. Not only for leaders, but honesty is also considered as a handle of life for each individual and used as a good personal benchmark for the Buginese, while honesty for a leader is a must. Dishonest leader can be a source of problems and the cause of the failure of a government.

Orwell tells the leader in Animal Farm, Napoleon, is a dishonest leader. This dishonesty was shown starting from Napoleon's ambition to take over the sole leadership of Napoleon. Napoleon secretly separated the nine puppies from his mother and then secretly Napoleon trained the dog. The aim is to become a weapon when attacking Snowball later.

After the departure of snowball, Napoleon still always blamed Snowball form every problem arose on the farm. Napoleon always spreads information if all the problems that arise are Snowball. Squealer is a spokesman and he also not an honest person. He is so good at talking to make animals believe what he says. Squealer did everything to help Napoleon and also made Napoleon feel more powerful as the sole leader of the farm.

In a story about how important the lempu is, there is a story about Datu Soppeng, La Baso to Akkarangeng is punishing itself for a crop failure in Soppeng. In the cultural beliefs, crop failure is a punishment from Pawinruk-E, the creator. This happened because of violations of the law that were not tried. Finally, Datu asked Pabbicara who is a royal law enforcer to find out violations that might occur.

However, Pabbicara did not find the violation. Suddenly the Datu was shocked and realized that actually he was the source of the disaster that he was looking for. At one time he picked up a bag of goods, the owner did not know about and the goods were not distributed according to the Pangandereng. So that the punishment from Pawinruk-E is not getting bigger, finally Datu sentenced himself for his actions that were not in accordance with common law.

Dato Soppeng shows that he is an honest one. He admits their mistakes and be willing to be punished according to applicable regulations. if at that time Dato Soppeng was reluctant to admit his mistakes honestly, somehow the fate of the kingdom he led had never rained. Therefore, the plates are considered inappropriate and are not found in Animal Farm stories.

\subsubsection{Getteng (Firm)}

Getting means firm. Firm is here explicitly meant in this case is how a leader can be firm in implementing the rules that apply to the organization or community he leads. Firm stance is also part of the firmness. How a king can stand firm, if he has said or decided something it is an absolute decision and cannot be easily interrupted.

About assertiveness was also exemplified by a spokesman for king of Sidenreng. His name is La Pagala bu known by the name Nenek Mallomo. In order to become a leader who upholds honesty and decisiveness, he voluntarily handed down his death sentence on his biological sons who accidentally took wood that was leaned on a tree trunk. Actually, his son did not intend to steal, but the law is still the law. Nenek Mallomo was proven to steal wood based on the rule that the wood leaning on a tree or fence is someone else's property. Through this story Nenek Mallomo is remembered for all time. 
La Inca Petta Mabboco - bocoE MatinroE ri Addenna. Around 1595 the eighth King of Bone was considered to have committed arbitrariness. The most inherent thing is the La Inca likes to kidnap and marry the virgin girl of its people by force.

Even when there is a newlywed couple and La Inca is attracted to the bride, La Inca sleeps with the bride first before her own husband which is the person most entitled to it. This is the reason why La Inca was named Petta Mabboco - bocoE, because he likes to be in a mosquito net. Boco in Buginese language means mosquito net.

The common law decided that Raja Bone must be sentenced for his actions. Decisions handed down are decisions that are considered commensurate with what has been agreed upon. The penalty is dead execution.

Traditionally, those allowed to carry out executions were close relatives of Raja Bone and the customary choice fell to Arung Majang. He is the grandfather of La Inca. In another version it is told when the people could no longer stand the treatment of the king, the people finally attacked the king on the basis of law enforcement.

In a desperate situation, La Inca ran toward his grandfather's house. when entering the yard of his grandfather's house, people who chase him stop in front of the gate because it is customary law, should not enter someone's home page if the homeowner does not invite and when someone who is in trouble comes for help, the homeowner should help.

This is the other story about how law becomes so powerful. From this story can be seen how Nenek Mallomo thought that the law does not know children or grandchildren. When someone does something that violates the applicable law, he should be given appropriate punishment. even though he is a king. as the highest office holder in a kingdom.

After learning of the problem, Arung Majang finally executed his own granddaughter by stabbing La Inca. The incident happened on the steps of the house; this is the background of La Inca being named MatinroE ri Addenenna which means sleeping on the stairs

In the story of Animal Farm, it is depicted that Napoleon was a person who was strict with his followers. The basis of the difference with Buginese perspective is that not only the king should be firm, but the people can also be firm in defending the truth. If the king is considered wrong, the people can ask the royal judge to punish anyone who is guilty.

The animals on the Farm seem to only follow Napoleon's instructions and fully trust in Squealer. Although there are some who are aware, but they feel that they are not powerful enough to speak the truth. Based on the results of the analysis of firm values that are consistent with Buginese perspective also not found in the story.

\subsubsection{Ada Tongeng (Correct Word)}

Ada tongeng is correct word. Correct word means tell the truth. there is no addition or reduction information for any reason. Ada tongeng also very much related to honesty. When the words are true, they must be conveyed honestly. This is one of values in leadership value according to Buginese perspective. This is certainly very contrary to the events that occurred in the story of Animal Farm. Napoleon and other pigs amended the seven commandments without the approval of other animals. Then when there are animals that are aware of these changes, Squealer as a spokesperson tries to explain with chronological manipulative and the reasons for the amendment.

The story about Nenek Mallomo can also be used as a benchmark about a tongeng. Nenek Mallomo holds the leadership value. His position as a spokesperson at that time could have been used as a vehicle to save his child. but Grandma Mallomo remained steadfast in conveying kindness. 
On the other hand, ada tongeng was also clearly violated when boxers were sold to slaughterhouses and then told other animals that Boxer died in the hospital. Then the pigs bought a box of whiskey from the sale of Boxer to the slaughterhouse. Based on this it can be shows that the value of ada tongeng is also considered to be at odds with the Animal Farm story.

\subsubsection{Sugik (Rich)}

Sugik means rich. In this case, rich are not only about money but the definition of sugik here is wider than that. Sugik according to MaccaE ri Luwu is about rich in word, rich in thought or mind, rich in work and rich in shopping or spending the money for the members of community. Rich in word means good word that used when a leader talks to anyone in that community. Rich in thought means how clever the leader and full of consideration before decide something that is related to the whole community. Rich in work means the leader do the job that he supposed to do. He becomes a responsible one for all of his job. Rich in shopping or spending is the leader is not become a greedy one. He always takes care the whole members including make sure that all his member has some enough food to stay alive. In Orwell Animal Farm shows that Jones, the owner of Manor Farm not really care about all of animal in his farm. The way he treats the animal can be define as a careless person. He lets all the animal stay hungry but he still wants to get money from the milk and eggs. In Napoleon era, in winter, Napoleon and all the pigs stay warm inside the farm house while other animals stay cold and hungry outside. This is one of the differences of leadership values in Orwell Animal Farm and leadership in Buginese perspective.

\subsubsection{Macca (Clever)}

A person's intelligence level is something that can be considered before giving the mandate as a leader. Intelligence in question is the capability of someone in carrying out a task.

In the story of Animal Farm, it was clearly stated by Orwell that pigs are the smartest animals. After pigs, dogs come in second. Because of that the pig was appointed to be the leader of other animals. One example of pig intelligence is that only pigs can read and pigs also design windmill construction.

Smart is also included as one of the leadership values based on Buginese perspective. This is the similarity that researchers found after analyzing the value of leadership in the Animal Farm story seen through leadership value in Buginese perspective.

\section{Conclusion}

Animal Farm showed about a group of animals that leads by pigs did a rebellion against the owner of the farm. This is become the beginning of the story. The researcher analyzed the story to find the leadership value in Orwell's Animal Farm.

Beside that the researcher showed the contradictory of leadership value in the Orwell Animal Farm with Buginese perspective. There are five benchmarks that showed in Buginese perspective. They are firm, honest, true word and careless. Those four values are totally contra with the cases in the story. The only leadership value in Buginese perspective that is has similarity with leadership value that portrayed in Animal Farm story is clever. 


\section{Acknowledgements}

I gratefully acknowledge that this research I present to both of my lovely parents Almarhumah Hadijah Mustafa and Andi Mursalin. Thank you for all of prayers, love, supports. I thank to all of my big family Fada Family and Sinrang Family.

\section{References}

[1] R. Wellek and A. Warren, Theory of literature. Harcourt, Brace \& World New York, 1956.

[2] B. E. Winston and K. Patterson, "An integrative definition of leadership," Int. J. Leadersh. Stud., vol. 1, no. 2, pp. 6-66, 2006.

[3] M. H. Abrams, The mirror and the lamp: Romantic theory and the critical tradition, vol. 360. New York: Oxford University Press, 1971.

[4] Lewis, Applied the Objective Approach. London: Oxford University Press, 1976.

[5] A. Ibrahim, Sulesana: kumpulan esai tentang demokrasi dan kearifan lokal. Penerbit Lembaga Penerbitan, Universitas Hasanuddin, 2003.

[6] G. Orwell, “Animal Farm.” London, Penguin, 1951.

[7] S. Machmud, Setetes Embun di Tanah Gersang. 1st ed. Makassar, South Sulawesi Indonesia: Pustaka Sawerigading, 2015. 